\title{
THE ANALYSIS OF ASPECTS OF FOOD INDUSTRY COMPETITIVENESS IN SERBIA
}

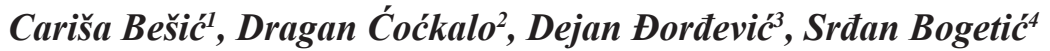

\begin{abstract}
Summary
Competitive ability of the company in modern business conditions is difficult to achieve and easy to lose. The reason for this attitude is the fact that the rapid technological improvement enabled the technology with becoming available to everyone in the world under reasonable terms. Competitiveness of domestic companies is very low. Insufficient application of knowledge, low technological level of enterprises, unproductiveness and inefficiency are just part of the problem. Food industry in Serbia shares the fate of domestic economy non-competitiveness is one of the main factors which affect the crisis in agricultural sector. The authors of this paper, based on the available national and international statistical data, have done analysis and display of competitive opportunities of domestic economy in general and in particular sectors of food industry. The authors also indicate the possibility of improving competitiveness.
\end{abstract}

Key words: competitiveness, food industry, quality, management.

JEL: $L 15, Q 13$

\section{Introduction}

Competitive ability of the company with modern business conditions is difficult to achieve and easy to lose. The reason for this attitude is in the fact that rapid technological advances enabled technology to be available to everyone in the world under reasonable terms. In

1 Cariša Bešić, Ph.D., Associate Professor, University of Kragujevac, Faculty of technical science, 32000 Čačak, Svetog Save Street no. 65, Serbia, Phone: +381 60369 96 96, E-mail: carisa.besic@sbb.rs

2 Dragan Ćoćkalo, Ph.D., Associate Professor, University of Novi Sad, Technical faculty "Mihajlo Pupin” in Zrenjanin, 23000 Zrenjanin, Đure Đakovića Street bb, Serbia, Phone: +381 6280197 41, E-mail: cole@ttzr.uns.ac.rs

3 Dejan Đorđević, Ph.D., Full Professor, University of Novi Sad, Technical faculty "Mihajlo Pupin" in Zrenjanin, 23000 Zrenjanin, Đure Đakovića Street bb, Serbia, Phone: +381 6280197 26, E-mail:djole@rocketmail.com

4 Srđan Bogetić, Ph.D., Professor, Belgrade Business School, 11000 Belgrade, Kraljice Marije Street no. 73, Serbia, Phone: +381 6412542 92, E-mail: sbogetic@yahoo.com

EP 2014 (61) 3 (647-659) 
addition, global economic crisis has highlighted the necessity for creating new business models. Competitiveness and business excellence are interconnected phenomena. A company cannot be competitive if it is not business excellent and vice versa.

Competitiveness of domestic enterprises is on a very low level. Insufficient application of knowledge, low technological level, unproductiveness and inefficiency are just part of the problem that domestic companies face.

Food production is a significant export potential of Serbia, but it is not implemented enough due to weak competition of the companies and products themselves. The local food industry contributes significantly to domestic exports. The greatest export contribution in 2013 yielded the following areas: motor vehicles and trailers - a share of $17.6 \%$, followed by the production of food products - accounted for $13 \%$ and agricultural production, hunting and related service activities - share of $8.3 \%$. When we observe the period from January until November 2013 compared to the period from January until November 2012, we can see that food products grew by about $8 \%$. As has been showed by official statistics, the food industry is located immediately behind the production of motor vehicles in the share of exports, and has recorded a growth of production. On the other hand, although these are positive indicators, the domestic food industry has not achieved all its features. One of the main problems of companies in the food industry, and the main problem of the domestic economy as well, is the lack of competitive abilities. When we talk about specific aspects of competitiveness which should be improved in the domestic economy, we must emphasize quality, productivity and innovation.

\section{The Analysis of the Aspects of Competitiveness in Domestic Economy}

Since the beginning of the $80 \mathrm{~s}$, the local economy has had problems with productivity improvement. Improving the productivity is certainly a pressing problem in most countries in transition, as well as in the local economy. The problem of productivity was not reported to the local economy during the transition, but it had been present before. The problems of labor productivity of domestic enterprises were the result of inadequate ways of doing business, which was not based on market principles. Thus, it resulted in unrealistically high prices of certain products, which were not competitive on the world market. Therefore, domestic enterprises, in order to successfully compete on the world business stage, lowered export prices, while the difference was paid by domestic consumers through high prices. Outdated technology, poor quality, unattractive packaging and high prices are the main reasons why Serbian products cannot compete with other competing products in the international market (Đorđević et al., 2011).

According to the list of the World Economic Forum in 2013, Serbia was ranked on the $101^{\text {st }}$ place out of the 148 countries that had been reviewed. Serbia is on the $95^{\text {th }}$ place on the list for 2011 and 2012, which means that there is development in competitiveness, but in a negative sense. An interesting fact is that this year, Serbia found itself in the company of Algeria $\left(100^{\text {th }}\right.$ place) and Guyana (102 ${ }^{\text {nd }}$ place). Our last year "neighbors", also significantly changed their status - Argentina is "down" for 10 places (now on 104 $4^{\text {th }}$ ), whereas Greece moved up five 
places (now 91 ${ }^{\text {st }}$ ). Table 1 shows the ranking of the countries of the Western Balkans in 20092013. Serbia and Slovenia recorded a decline on the list - Slovenia has recorded a significant decline in comparison to other studied countries. Also Montenegro and Croatia recorded a slight decline from 2009-2013.

Table 1. Ranking Western Balkan countries according to competitiveness in the period 2009-2013

\begin{tabular}{|l|c|c|c|c|c|}
\hline \multicolumn{1}{|c|}{ Country } & $\begin{array}{c}\text { Rank in } \\
\mathbf{2 0 0 9 .}\end{array}$ & $\begin{array}{c}\text { Rank in } \\
\mathbf{2 0 1 0 .}\end{array}$ & $\begin{array}{c}\text { Rank in } \\
\mathbf{2 0 1 1 .}\end{array}$ & $\begin{array}{c}\text { Rank in } \\
\mathbf{2 0 1 2 .}\end{array}$ & $\begin{array}{c}\text { Rank in } \\
\mathbf{2 0 1 3 .}\end{array}$ \\
\hline Slovenia & 37 & 45 & 57 & 56 & 62 \\
\hline Montenegro & 62 & 48 & 60 & 72 & 67 \\
\hline Croatia & 72 & 77 & 76 & 81 & 75 \\
\hline Macedonia & 84 & 79 & 79 & 80 & 74 \\
\hline Serbia & 93 & 96 & 95 & 95 & 101 \\
\hline B\&H & 109 & 102 & 100 & 88 & 87 \\
\hline
\end{tabular}

Source: World Economic Forum, 2008-2013.

From the countries from our close environment, in 2013, Hungary is situated on the $63^{\text {rd }}$ place, Bulgaria on the $57^{\text {th }}$, Romania is situated on the $76^{\text {th }}$, Greece, as has already been mentioned, is placed on the $91^{\text {st }}$ and Albania on the $95^{\text {th }}$. As can be seen from Table 1 Serbia has a problem with global competitiveness in the last five years, and it was particularly evident in the 2013 - Serbia had the worst position in relation to all compared countries, not only in the Western Balkans, but also in the neighbouring area of south Eastern Europe.

Table 2 provides a ranking of the Western Balkan countries according to competitiveness indicators. The basic requirements of competitiveness consist of the following indicators - institutions, infrastructure, macroeconomic environment, health and primary education, high education and training, goods market efficiency, labor market efficiency, efficiency of capital markets, technological capacity and market size. As can be seen, Serbia is slightly better when it comes to efficiency of doing business. When it comes to innovation, according to World Economic Forum, all countries in the world are divided into five groups. The first group consists of countries whose economies are based on application and development of innovative activities (this group consists of 37 countries). THE second group consists of countries in transition from the first to the third group (this group has 20 countries) and the fourth group consists of countries in transition from the third to the fifth group of countries (in this group there are 22 countries). Serbia is located in the third group (economy keeping efficiency), together with Montenegro, Romania, Bulgaria, Macedonia, Bosnia, Albania, Indonesia, and Chile. Croatia is in the fourth group (transition from efficiency to innovation), while Slovenia is located in the fifth group of countries that stem (economy driving innovation and sophistication). The fifth group mainly consists of the most developed countries in the world. 
Table 2. Ranking Western Balkan countries according to indicators of competitiveness in the year 2013

\begin{tabular}{|l|c|c|c|c|}
\hline Country & $\begin{array}{c}\text { Rank in } \\
\mathbf{2 0 1 3 .}\end{array}$ & $\begin{array}{c}\text { Ranking } \\
\text { according } \\
\text { to primary } \\
\text { requirements }\end{array}$ & $\begin{array}{c}\text { Ranking } \\
\text { according to the } \\
\text { efficiency of } \\
\text { business }\end{array}$ & $\begin{array}{c}\text { Ranking } \\
\text { according to } \\
\text { innovation }\end{array}$ \\
\hline Slovenia & 62 & 37 & 62 & 49 \\
\hline Montenegro & 67 & 68 & 72 & 70 \\
\hline Croatia & 75 & 61 & 68 & 80 \\
\hline Macedonia & 74 & 70 & 76 & 94 \\
\hline Serbia & 101 & 106 & 92 & 89 \\
\hline B\&H & 87 & 87 & 89 & 89 \\
\hline
\end{tabular}

Source: World Economic Forum, 2008-2013.

The World Economic Forum provides an analysis in the field of sustainable development, from the aspect of social sustainability and sustainability in environmental protection (see Table 3. for the Western Balkan countries). The main pillars of the social indices of sustainable development are: income, youth unemployment, access to sanitation, access to potable water, access to health services, social welfare, own contribution of gray economy in the economy, social mobility, the overall unemployment rate. The main pillars of the index in protecting the environment include power of legislation, protection of land, the number of ratified international protocols and agreements, availability of water for agriculture, exposure to carbon dioxide ratio for fishing, concentration of particles in the air quality of the environment.

Table 3. Ranking Western Balkan countries according to the analysis of the factors of sustainable development in 2013

\begin{tabular}{|l|c|c|c|}
\hline Country & $\begin{array}{c}\text { Ranking according to } \\
\text { social sustainability }\end{array}$ & $\begin{array}{c}\text { Ranking according to } \\
\text { sustainability in the } \\
\text { field of environment }\end{array}$ & $\begin{array}{c}\text { A change in } \\
\text { comparison to } \\
\text { the previous period }\end{array}$ \\
\hline Slovenia & 4.68 & 4.60 & Slight increase \\
\hline Montenegro & 4.13 & 4.13 & Stagnation \\
\hline Croatia & 4.09 & 4.13 & Stagnation \\
\hline Macedonia & 3.99 & 3.83 & Stagnation \\
\hline Serbia & 3.58 & 3.74 & Stagnation \\
\hline B\&H & 3.66 & 3.44 & Slight decrease \\
\hline
\end{tabular}

Source: World Economic Forum, 2008-2013.

Considering standards and certification, the situation in South East Europe is still unsatisfactory. For instance, although there was noted an uptrend in this field, especially in Romania which is one of the countries with the biggest number of certificates, on average, the number of certificates is still small. As for the number of certified organizations on domestic market, there has been a slight decrease from the previous year, but Serbia is still a leading country of the Western Balkans region (Figure 1). The number of certified organizations in Serbia has contributed to a better position of our economy when it comes to improving 
business efficiency. As a parameter of global competitiveness - based on the level of business efficiency, Serbia is on the $92^{\text {nd }}$ position, while regarding the level of innovative spirit, it is on the $125^{\text {th }}$ position of the global scale. On the other hand, the number of certified organizations in Serbia is not nearly satisfactory compared to the other SEE countries, such as Hungary, Romania, Bulgaria and Greece.

Figure 1. Number of certificates of ISO 9001 and ISO 14001 in the Western Balkans

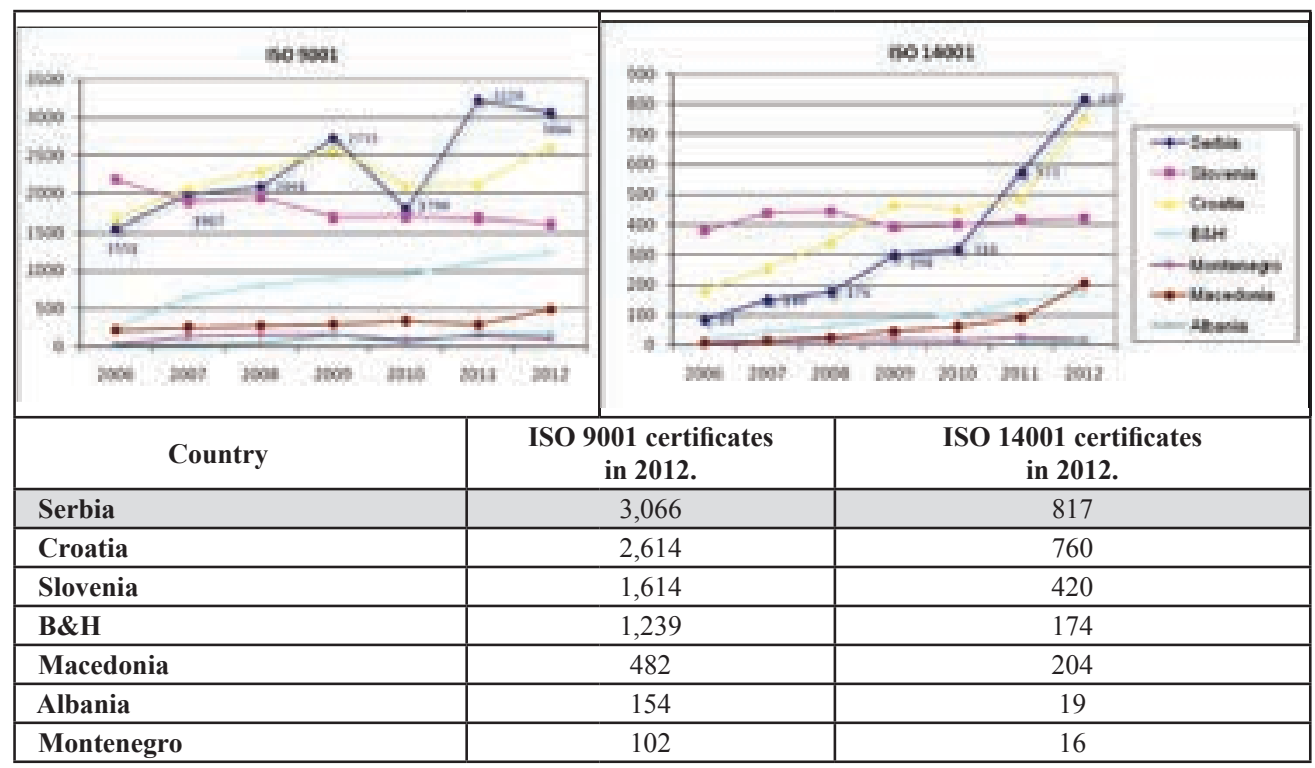

Source: ISO, 2006-2012.

Productivity accounts for $42 \%$ of European average. The reason is insufficiently good organization of business, technological backwardness and the lack of knowledge, but the consequences are non-competitiveness and a decrease in consumption of employment. The most productive companies are those with the equipment and machinery of the top quality. These are part of the food and pharmaceutical industries and companies with constant capital, which together accounts for 8.5 to nine per cent of Serbian industry. The average age of vehicles in Serbia is 29.5, which is two decades behind the EU average (Table 4). This is determined on a representative sample of 154 small, medium and large companies in six industries with similar production programmes. Austria has been taken as a criterion since it is approximately similar to the natural, social and population characteristics of Serbia. The companies in the field of textiles (35), followed by companies from the machine industry (34.5 years). The pharmaceutical companies lag behind the least with a delay of 21 years. Regionally observed, equipment, tools and other productive resources are the most obsolete in the region of southern Serbia (41 years), and the best situation is in the region of Bačka (lag of 18.5 years). In Belgrade, technological lag is 20.5 years. 
Table 4. The average age of machines and equipment in Serbian industry sector

\begin{tabular}{|l|c|}
\hline \multicolumn{1}{|c|}{ Industry Sector } & The Average Age (years) \\
\hline Textile Industry & 35.1 \\
\hline Machine Industry & 34.6 \\
\hline The Pharmaceutical Industry & 21 \\
\hline Food Industry & 27.1 \\
\hline Chemical Industry & 28.6 \\
\hline The Construction Industry & 30.5 \\
\hline
\end{tabular}

Source: Ekonomist EMG, 2012.

The research of the Union of Employers of Serbia, which deals with the analysis of effective work in the local companies, has been conducted on a sample of 242 companies that employ more than 15,000 workers. The survey results point to the fact that few people in Serbia who work full-time, i.e. 8 hours a day - account only for 9.4\%. Furthermore, $17.4 \%$ of workers work effectively for 5 hours per day, $16.5 \%$ of workers work effectively for 3 hours per day, and $1.2 \%$ of workers work effectively for 1 hour a day. In domestic enterprises $23.2 \%$ of workers use a break for 1 hour, and $22.9 \%$ of workers use a break of 30 minutes.

Last but not least, innovation is an important factor in establishing, maintaining and developing competitive ability of companies. Innovative activity requires substantial financial resources, and local businesses have had a chronic lack of money since almost three decades ago. This indicates that domestic companies invested very little in research and development activities in that period.

\section{The Analysis of Competitiveness of Domestic Food Industry}

Domestic food processors share the fate of domestic economy. The problems of these companies are numerous, but it is believed that the lack of competitiveness is one of the main factors affecting the agricultural sector crisis (Pejanović et al., 2013).

The average age of equipment in the food industry is somewhat better than the rest of the national economy and is 27.1 years, while the average age of vehicles in domestic economy is 29.5 years. The fact that the average age of vehicles in the most developed EU countries ranges from 5.1 in Germany to 9.1 in Italy illustrates this phenomena best. The countries which have completed the process of transition, such as Romania and Bulgaria, the average age of vehicles is 16.9 and 17.3 years (Ekonomist EMG, 2012).

Like most companies in the field of manufacturing, domestic food companies produce products that fall into the products with low manufacturing prices and a significant portion is in the lower stages of finalizing the product. The structure of exports in accordance to the product structure is given in Table 5.

When it comes to the success of enterprises in the food industry (on the list for 2012), there are only two companies in this field - Sunoko Ltd. Novi Sad on the fifth place and Imlek AD Beograd on the tenth place (Table 6). Thus, in the national context, the enterprises in the food industry cannot compete with the companies from the fields of automotive 
industry, petrochemicals, telecommunications, and chemical industry. When it comes to the most successful exporters in 2013 (SIEPA, 2014b), we cannot find a company from food industry among the first fifteen domestic exporters.

Table 5. The export of products in the period from January to December 2012

\begin{tabular}{|c|l|c|}
\hline No. & \multicolumn{1}{|c|}{ Product } & Export given (in million USD) \\
\hline 1 & Yellow corn & 541 \\
\hline 2 & White sugar & 164 \\
\hline 3 & Raspberry & 136 \\
\hline 4 & Sunflower oil & 96 \\
\hline 5 & Non-alcoholic beverages & 64 \\
\hline 6 & Soya oil & 55 \\
\hline 7 & Beer (bottled) & 53 \\
\hline 8 & Wheat & 51 \\
\hline 9 & Cherry & 48 \\
\hline 10 & Wheat flour & 45 \\
\hline
\end{tabular}

Source: Serbian Chamber of Commerce, 2014a

Table 6. The most successful enterprises in Serbia in 2012

\begin{tabular}{|c|l|c|c|}
\hline No. & \multicolumn{1}{|c|}{ Company } & $\begin{array}{c}\text { Net income } \\
\text { (in 000 RSD) }\end{array}$ & $\begin{array}{c}\text { The number of } \\
\text { employees }\end{array}$ \\
\hline 1 & NIS & $49,456,516$ & 7,577 \\
\hline 2 & Telekom Srbija AD & $11,251,155$ & 9,061 \\
\hline 3 & Telenor DOO & $10,580,559$ & 1,131 \\
\hline 4 & Tarket DOO & $9,770,211$ & 729 \\
\hline 5 & Sunoku DOO Novi Sad & $6,077,056$ & 471 \\
\hline 6 & Pertil DOO Bačka Palanka & $3,051,771$ & 109 \\
\hline 7 & HE Đerpad DOO Kladovo & $2,996,167$ & 1,001 \\
\hline 8 & Hemofarm AD Vršac & $2,790,789$ & 1,688 \\
\hline 9 & Tigar Tyres DOO Pirot & $2,758,621$ & 2,067 \\
\hline 10 & AD Imlek Beograd & $2,670,444$ & 828 \\
\hline
\end{tabular}

Source: Biznis i finansije, 2014.

One of the problems caused by inadequate competitiveness of domestic enterprises in the food industry is a weak market position of domestic brands. Insufficient investment in marketing activity during the transition period, combined with the subsequent entry into the standardization process sacrificing business, resulted in insufficient recognisability of brands of domestic food enterprises beyond Serbia. According to some research (Biznis i finansije, 2005), domestic brands are very poorly recognized in the Western Balkans. Specifically, the study included an analysis of recognition brands in Slovenia, Croatia, Bosnia and Serbia. The study showed that among the top ten brands there are only three local brands and one from Slovenia (Paloma), Croatia (Vegeta) and Serbia (Grand coffee), and the rest were international brands. 
Regarding the implementation of international standards of management in the organizational structure of local companies in food industry and according to the Serbian Chamber of Commerce (2014b), 202 companies have a type of international certificate. The majority of companies in the food industry, 176 of them, own the certificate of implemented HACCP system, followed by 64 enterprises with a certificate of ISO 9001, and 22 companies that have introduced a certificate of ISO 22001. As for the companies that belong to agricultural sector, 15 of them possess some international management standards. According to the ISO Survey in 2012 and according to ISO 22000 there were 172 certified enterprises. According to the Ministry of Agriculture, 800 companies have applied for certification, and nearly 450 have already received HACCP certification (SIEPA, 2014a). As can be seen, the data significantly diverge from source to source, but it is significant that more and more companies realize the importance, relevance and necessity of introducing quality standards in order to enhance their business not only in Serbia but also for the sake of export to foreign markets.

Clusters represent one certainly important way of improving competitiveness of domestic enterprises (Ilić, 2006; Zdravković, 2011; Milojković, Stojković, 2012). Only four clusters out of the total number of all organized ones in Serbia are related to agriculture and food industry. Those clusters are: BIPO Cluster - Balkan-Black Sea Industry of Agricultural Machine, Sumadijski flower - the cluster of flowers manufacturers, Agribusiness and food producers Cluster - Pollux. The first two clusters belong to the second development phase while the other two include the initial initiative from the first phase (Đorđević et al., 2012).

\section{The Possibilities for Improving the Competitiveness}

The application of modern methods and techniques of management is certainly the easiest way to improve competitiveness of domestic enterprises. Also, the establishment of cooperation between large and small and medium-sized enterprises, the formation of strategic alliances and clustering are also directions for the development of competitiveness, especially in the food industry.

According to some beliefs, the main directions of development of competitiveness of agribusiness in the future can be observed (Milićević, 2013):

- positioning of large agribusiness corporations on domestic market,

- export of highly profitable products,

- promotion of agribusiness in small and medium-sized enterprises,

- establishment and development of cooperatives in agribusiness,

- protection of domestic markets and producers.

Faster and more comprehensive foster from international standards and integrated management systems should be certainly added as well as investing in domestic brands development. According to the famous theorist of marketing, Philip Kotler (2003), marketing skills are mostly reflected in the art of creating a brand. When something is not a trademark, it will probably be considered a commodity. Then the price is important. When 
the price is the only factor, a manufacturer that has the lowest cost is the only who gains. Great brands are the only path to a permanent, above-average profitability. Great brands do not offer only rational, but also emotional benefits.

The research results (Đorđević et al., 2013) obtained from the analysis of the attitudes of young people in relation to understanding the success of business practices of local businesses, show reflection of future professionals and managers and indicate the following:

- $\quad 45.7 \%$ of respondents believe that competitiveness of domestic enterprises does not meet the requirements set by the international environment, and $45.17 \%$ think that competitiveness of domestic enterprises partially meets the requirements set by the international environment, while only $5.56 \%$ of respondents believe that domestic firms meet these requirements and only $3.58 \%$ said that competitiveness is satisfactory;

- The most important factors that are missing in development of competitiveness of domestic enterprises are: new technology (12.42\%), education $(12.39 \%)$, motivation of employees (10.75\%), financial support $(9.36 \%)$ and state's institutional support (7.63\%). When it comes to assessing the level of innovation of domestic enterprises, the majority of respondents, $46.49 \%$ believe that local companies partially fulfil this factor of competitiveness, $36.95 \%$ of them believe that domestic companies do not meet competitiveness factor, $7.68 \%$ of respondents believe that domestic enterprises are innovative, while only $8.87 \%$ of respondents believe that the local companies are very innovative;

- The respondents, as necessary elements for the development of competitiveness of domestic enterprises, listed standardization of business quality $(18.67 \%)$, application of modern methods and techniques of management $(17.72 \%)$, investment in development of national brands $(12.32 \%)$ and the purchase of modern equipment and technology $(11.48 \%)$.

Based on the presented results we can conclude that young professionals in the field of management are aware of the fact that standardization of the quality of operations and the application of modern methods and techniques of management represent the strategic framework for the establishment of competitiveness of domestic enterprises, as well as competitiveness of domestic enterprises and the degree of innovation. According to the results of another study which analyzed the application of modern management techniques in domestic enterprises (Bešić et al., 2013), based on the analysis of the attitudes of local officials, the main obstacles in the development of competitiveness of domestic enterprises can be the following: lack of financial capital (20\%), lack of knowledge (18.6\%), outdated equipment and technology (15.9\%), insufficiently stimulating business environment (13.1\%), inadequate use of modern methods and techniques of management (12.4\%). Necessary elements for development of competitiveness of domestic business organizations are: improving business productivity $(21.3 \%)$, permanent training of management and employees (18.4\%), investment in development of national brands (15.4\%) growth of entrepreneurial culture in business environment (14.7\%), creating strategic alliances $(9.6 \%)$. According to research results, methods and management techniques to be applied in domestic business organizations are: 
- Database Management (18.4\%),

- Quality Management System (17.6\%),

- Corporate Social Responsibility (17.6\%),

- Relationship Marketing (16.8\%), and

- Benchmarking (12.6\%).

These data suggest that in times of crisis managers are fully aware of the fact that investment in employees and their skills, as well as investment in modern technology and equipment, are the most important factors defining the competitive viability of enterprises in modern business.

Future companies will be made of teams which will build and use their knowledge about market requirements and customers, suppliers and partners to be able to respond quickly through sophisticated electronic links to changes in fashion and economic circumstances. The process of value creation will be freed from all unnecessary actions (Acharol, Kotler, 2012; Hult, 2012; Mele et al., 2014).

\section{Conclusions}

Domestic companies are not sufficiently competent on the international market, and the main problem is the lack of competitive ability and poor productivity of domestic companies as well as non-standardized product quality. Productivity is low because of obsolescence of equipment and technology solutions, on one hand, and because of inadequate employment, on the other hand, especially in state-owned enterprises and in public sector.

One of the problems of food industry is still not enough established competition on foreign markets (Pejanović et al., 2009). There are several reasons for this, but the most important are: disorganized appearance on foreign markets, lack of funding performance in foreign markets, the continued product quality and the lack of certain certificates (HACCP, GLOBALGAP, Halal certification, etc.), (Đuran, 2011).

According to Besic (2006), one of the most important problems of domestic economy, which in large extent causes poor market performance of our enterprises on the international market is certainly inadequate use of knowledge, primarily referring to the knowledge necessary for the effective management of enterprises. Management is most responsible for the affairs of the organization. The greatest responsibility of managers is to properly manage the organization's resources to achieve profit.

In order to improve competitiveness of domestic economy, it is necessary to work more on expansion of ideas of quality improvement on national level. On the other hand, every business organization needs to become aware of the fact that the only way to establish, maintain and develop its competitive capabilities assumes constant improving quality performance and achieving the objectives of business excellence. 


\section{References}

1. Acharol, R. S., Kotler, P. (2012): Frontier of the marketing paradigm in the third millennium, Journal of academic marketing science, vol. 40, no. 1, pp. 35-52, Springer.

2. Bešić, C. (2006): Benčmarking - put ka poslovnoj izvrsnosti, Zadužbina Andrejević, Beograd, Srbija.

3. Bešić, C., Krnjević-Mišković, Z., Đorđević, D. (2013): The role of knowledge in the development process of competitive ability of domestic companies on the global market, Proceedings, III International Conference LEMiMA 2013, Belgrade, Serbia, pp. 214-220.

4. Biznis i finansije (2014): Biznis Top 2012/2013, Beograd, Srbija, (available at: http://bif. rs/2013/11/biznis-top-201213 accessed at: 13.03.2014)

5. Biznis i finansije (maj 2005): Najuspešnije marke u Srbiji i regionu, Biznis i finansije, Poseban dodatak - Hrana, str. 21, Beograd, Srbija.

6. Đorđević, D., Bogetić, S., Ćoćkalo, D., Bešić, C. (2012): Cluster development in function of improving competitiveness of SMEs in Serbian food industry, Economics of Agriculture, vol. 59, no. 3, pp. 433-446, IAE, Belgrade, Serbia.

7. Đorđević, D., Ćoćkalo, D., Bogetić, S. (2011): Novi model upravljanja i razvoj konkurentske sposobnosti domaćih preduzeća, Zbornik radova Konferencije JUSK ICQ 2011, IV konferencija Razvoj poslovne izvrsnosti i konkurentnost domaćih preduzeća, Beograd, Srbija, pp. 71-74.

8. Đorđević, D., Coćkalo, D., Bogetić, S. (2013): Perspektive razvoja konkuretnosti domaćih preduzeća, Zbornik radova Međunarodne konvencija o kvalitetu - JUSK ICQ 2013, Beograd, Srbija.

9. Đuran, J. (2011): Entrepreneurship as a factor of sustainable development of agroeconomics in the Republic of Serbia, Agroekonomica, vol. 51-52, pp. 165-173, Faculty of Agriculture, Novi Sad, Serbia.

10. Ekonomist EMG (12 ${ }^{\text {th }}$ April 2012): Posustajanje industrije Srbije, br. 619-620, str. 1213, Beograd, Srbija.

11. Hult, G. T. M. (2012): A focus on international competitiveness, Journal of the Academy of Marketing Science, vol. 40, no. 2, pp. 195-201, Springer.

12. Ilić, M. (2006): Poslovni inkubatori i klasteri kao model razvoja malih i srednjih preduzeća u industriji, Industrija, vol. 34, no. 4, pp. 63-98, Ekonomski institut, Beograd, Srbija.

13. ISO: The ISO Survey 2006-2012, (available at: http://www.iso.org/iso/iso-survey accessed at: 13.03 .2014$)$

14. Kotler, P. (2003): Marketing od A do Z, Adižes, Novi Sad, Srbija.

15. Mele, C., Pels, J., Storbacka, K. (2014): A holistic market conceptualization, Journal of the Academy of Marketing Science, pp. 1-15, Springer.

16. Milićević, M. (2013): (Ne)konkuretnost konditorske industrije Srbije, III poljoprivredni forum - Hrana za Evropu, Subotica, Ekonomski institut, Beograd, Srbija, available at: http://www.ecinst.org.rs/sites/default/files/prezentacije/prezentacija miroslav miletic.pdf 
17. Milojković, D., Stojković, N. (2012): Training for cluster facilitators in function of cluster development in Serbia, in New Challenges in Changing Labour Markets, ch. no. 19, pp. 327-336, Institute of Economic Sciences, Belgrade, Serbia.

18. Pejanović, R., Cvijanović, D., Njegovan, Z., Tica, N., Živković, D. (2009): Problemi poljoprivrede Republike Srbije i mere za prevazilaženje krize, Ekonomika poljoprivrede, vol. 56, no. 2, pp. 221-230, IEP, Beograd, Srbija.

19. Pejanović, R., Glavaš Trbić, D., Tomaš Simin, M. (2013): About the causes of agriculture crisis it the Republic of Serbia, Economics of Agriculture, vol. 60, no. 2, pp. 253-264, IAE, Belgrade, Serbia.

20. Republički zavod za statistiku (2013): Mesečni statistički bilten, 11/2013, Beograd, Srbija, available at: http://webrzs.stat.gov.rs/WebSite/Public/PageView.aspx?pKey=69 accessed at: 13.03.2014.

21. Serbian Chamber of Commerce (2014a): Poljoprivreda, prehrambena $i$ duvanska industrija - Statistika, available at: www.pks.rs accessed at: 13.03.2014.

22. Serbian Chamber of Commerce (2014b): Sertifikati, available at: http://www.pks.rs/Aplikacije.aspx?aplikacija=sertifikati accessed at: 13.03.2014.

23. SIEPA (2014a): HACCP Standard, available at: http://siepa.gov.rs/sr/index/standardi/haccp.html accessed at: 13.03.2014.

24. SIEPA (2014b): Najveći izvoznici u 2013. godini, (available at: http://siepa.gov.rs/index/vesti/siepa-vesti/; accessed at 13.03.2014)

25. World Economic Forum: The Global Competitiveness Report 2008-2013, available at: http://www.weforum.org/reports accessed at: 13.03.2014.

26.Zdravković, B. (2011): International Business Prospects of Small and Medium Enterprises in Serbia, International Journal of Economics \& Law, no. 1, pp. 159-168, Central and Eastern European Online Library. 


\title{
ANALIZA ASPEKATA KONKURENTNOSTI PREHRAMBENE INDUSTRIJE U REPUBLICI SRBIJI
}

\author{
Cariša Bešič ${ }^{5}$, Dragan Ćoćkalo ${ }^{6}$, Dejan Đorđevič ${ }^{7}$, Srđan Bogetič ${ }^{8}$
}

\begin{abstract}
Apstrakt
Konkurentska sposobnost preduzeća se u savremenim uslovima poslovanja teško postiže, a lako gubi. Razlog za ovakav stav leži u činjenici da je brzi tehnološki napredak omogućio da tehnologija postane dostupna svima u svetu pod prihvatljivim uslovima. Konkurentnosti domaćih preduzeća je na vrlo niskom nivou. Nedovoljna primena znanja, nizak tehnološki nivou preduzeća, neproduktivnost i neefikasnost samo su deo problema. Prehrambena industrija u Srbiji deli sudbinu domaće privrede - nekonkuretnost je jedan od glavnih faktora koji utiče na krizu u sektoru poljoprivrede. Autori se u ovom radu, na bazi dostupnih domaćih i međunarodnih statističkih pokazatelja, bave analizom i prikazom konkurentskih mogućnosti domaće privrede u opšte, a posebno sektora prehrambene industrije. Autori takođe ukazuju na mogućnosti za unapeđenje konkurentnosti.
\end{abstract}

Ključne reči: konkurentnost, prehrambena industrija, kvalitet, upravljanje.

5 Prof. dr Cariša Bešić, vanredni profesor, Univerzitet u Kragujevcu, Fakultet tehničkih nauka, 32000 Čačak, Svetog Save 65, Srbija, Telefon: +381 6036996 96, E-mail: carisa.besic@sbb.rs

6 Prof. dr Dragan Ćoćkalo, vanredni profesor, Univerzitet u Novom Sadu, Tehnički fakultet "Mihajlo Pupin", 23000 Zrenjanin, Đure Đakovića bb, Srbija, Telefon: +381 6280197 41, E-mail: cole@tfzr.uns.ac.rs

7 Prof. dr Dejan Đorđević, redovni profesor, Univerzitet u Novom Sadu, Tehnički fakultet "Mihajlo Pupin", 23000 Zrenjanin, Đure Đakovića bb, Srbija, Telefon: +381 6280197 26, E-mail: djole@,rocketmail.com

8 Dr Srđan Bogetić, profesor, Beogradska poslovna škola, 11000 Belograd, Kraljice Marije 73, Srbija, Telefon: +381 6412542 92, E-mail: sbogetic@yahoo.com

EP 2014 (61) 3 (647-659) 